\title{
Interleukin-8 and Soluble intercellular adhesion molecule-1 in patients with ulcerative colitis
}

\author{
Mona M. Morsy , Magda I.M.EL Mahdy*and Wafaa H.A. Helmy \\ Internal Medicine , Clinical Pathology* and Pathology** Departments, Faculty of \\ Medicine for Girls, AL Azhar University
}

\begin{abstract}
:
Ulcerative colitis (UC) is a chronic inflammatory bowel disease, characterized by dysregulated local immune defense with constant influx of leucocytes, providing a basis for continuous intestinal inflammation. The present study was conducted to evaluate the serum and intestinal concentrations of interleukin-8 (IL-8) and soluble intercellular adhesion molecule-1 (sICAM-1) and their correlation with the disease activity. Twenty eight patients with ulcerative colitis (16 with active and 12 with inactive disease) and 12 subjects as a control group were included in the study. The patients and control group were subjected to the following investigations: colonoscopy and obtaining biopsy specimens, histopathological examination of biopsy specimen for assessment of disease activity score, assay of erythrocyte sedimentation rate (ESR), C-reactive protein (CRP), assay of IL-8 and sICAM-1 levels in sera and colonic biopsy specimens. The results showed that the serum and tissue IL- 8 concentrations were significantly increased in patients with active UC as compared to control group $(\mathrm{p}<0.001)$ and to inactive cases $(\mathrm{p}<0.001)$, but there were non significant difference between inactive and control groups $(\mathrm{p}>0.05)$. The results of sICAM-1 in sera and colonic mucosa showed significant increase in patients with active UC as compared to the control group $(\mathrm{p}<0.001)$ and as compared to inactive cases $(\mathrm{p}<0.001)$. There was non significant difference in sICAM level (in sera and tissue) between inactive patients and control group ( $p>0.05)$. Both IL-8 and sICAM-1 whether in sera or in tissue showed significant positive correlations with disease activity score and the inflammatory markers , (ESR and CRP) in patients with active UC. IL-8 in sera and tissue also showed significant positive correlation with sICAM-1 in patients with active UC. In conclusion, both IL-8 and sICAM-1 showed significant increase in patients with active ulcerative colitis as compared to control group and inactive cases, denoting that they might play a role in the inflammatory response and tissue destruction and that the assay of their serum levels could be simple, non-invasive tests for monitoring the disease activity in patients with ulcerative colitis.
\end{abstract}

\section{Introduction:}

Inflammation is one of the commonest disease entities and the diagnosis of its activity is frequently required for the initiation or the amen -dment of the relevant therapy. Diagnostic approaches have ranged from laboratory, radiological, endoscopic, or histological assessments (Pepys and Berger, 2001). Sometimes, surgical intervention, which could be unpleasant and complicated might be indicated to verify suspected cases, so less invasive approaches still needed for assessment of inflammatory conditions (Taha et al.,2001). 
Ulcerative colitis (UC) is a chronic inflammatory bowel disease (IBD) of unknown aetiology with prominent leuocyte infiltration (in acute stage), which is confined to the mucosa and superficial submucosa of the bowel wall and contributes largely to the tissue damage ( Mac Dermott et al., 1998).

The recruitment and activation of leucocytes in inflamed tissues is a complex process driven by chemokines and possibly other attractants that induce cell adhesion and location (Uguccioni et al., 1999). Interleukin-8 (IL-8) is a potent chemoattractant and activator of neutrophils. It is produced by a wide variety of cell types, inclu ding macrophages, neutrophils, endoth elial cells, fibroblasts, chondrocytes and osteoclasts ( Natarajan et al., 2001).

Intercellular adheoian molecule 1 (ICAM-1) seems to exhibit effects other than leucocyte / endothelial interaction, ICAM-1 has been shown to play an important role for migration of leucocytes from circulation toward colonic mucosa (chemotactic properties) epithelium (Vainer et al.,2000). ICAM-1 is a glycosylated protein of $90 \mathrm{KDa}$, belongs to the immunoglobulin superfamily and is expressed on activated endothelial cells and macrophages (Pedersen et al., 1996). The soluble form probably result from shedding of the parent molecule during local cellular immune responses (Nakata et al.,2000).

Both IL-8 and ICAM-1 are believed to be involved in the pathogenesis of UC. However, there has been no enough investigations of these molecules in relation to the degree of local inflammation and to what extent their production may be implicated in the inflammatory response in UC (Nielsen et al., 1998).

The aim of this study is to measure the concentrations of soluble
ICAM-1 and IL-8 in sera and intestinal biopsy specimens from patients with $\mathrm{UC}$ and to assess their correlations with the disease activity.

\section{Patients and methods:}

A total of 40 patients undergoing colonoscopy for diagnostic purposes in Internal Medicine Department of $\mathrm{Al}$ Zahraa University Hospital were included in this study. Twenty-eight patients (20 males and 8 females, aged 21-50 years old) fulfilled the criteria for UC (based on clinical ,radiological, endoscopic and histological criteria) (Langholz,1991). Twelve patients (9 males and 3 females, aged 22-51 years old) had normal colonoscopy and were subsequently found to fulfill the criteria for irritable bowel syndrome. They served as a control group. The patients and control were subjected to: medical history, full clinical examination, abdo minal plain x-ray, abdominal ultrason ography and routine laboratory investigations including (1) Complete blood picture (CBP) and erythrocyte sedimentatin rate (ESR).(2) C-reactive protein (CRP): using AVITEX- CRP rapid latex agglutination Kit (Omega Diagnostics, UK).(3) .Fasting blood glucose, blood urea, serum creatinine, alanine aminotransferase (ALT), aspa rtate aminotransferase (AST), alkaline phosphatase and albumin ( using Hitachi 911 chemistry auto-analyzer and Kits of Roch diagnostic). (4) stool analysis. Diarrhoea, abdominal pain and rectal bleeding were the main symptoms in UC patients. Six of the UC patients were receiving a combination of prednisolone and sulfasalazine, seven were on sulfasalazine only and fifteen were not receiving any treatment. Patients with diabetes mellitus. liver or renal diseases were excluded from the study. 
Endoscopic appearance of the colonic mucosa was assessed according to criteria of Cellier et al., (1997) as follows: Normal : smooth and shining mucosa, Mild : erythema, granulation and pinpoint vulnerability, Moderate: coarse or pinpoint ulcerations, Severe: gross ulcerations, vulnerability and spontaneous haemorrhage.

During colonoscopy biopsy specimens were taken, preferably from the most inflamed site and used for:

1-Histopathological examination:

One specimen was fixed in formalin, paraffin sections were made and slides were prepared and stained with haematoxlin and eosin for histopa thological examination. Histological disease activity was assessed according to the criteria of Truclove and Richard,(1956). The disease activity index scores as follows: $0=$ normal, $1=$ chronic inflammatory cells in lamina propria, $2=$ mild crypt injury with acute cell infiltrate and some crypt abscess, 3 $=$ marked crypt destruction with crypt abscesses and ulceration. Score 0-1 correspond to inactive disease and score 2-3 corresponds to active disease.

2-Tissue IL-8 and ICAM-1 :

The second specimen was put in $1 \mathrm{ml}$ of phosphate buffered saline $(\mathrm{PH}$ 7.4) , sonicated with ultrasonic homogenizer (IKASONIC U 50) and centrifuged at $800 \mathrm{~g}$ for 5 minutes. The supernatant was separated and then stored at $-20^{\circ} \mathrm{C}$ till time of assay of sICAM-1 and IL-8. The protein content of the supernatants were determined (Total protein in urine and CSF, Spinreact KIT) for standardizations of sICAM-1 and IL-8 .

Ten $\mathrm{ml}$ of blood were obtained from all patients, 1.4 was anticoagulated with $3.2 \%$ trisodium citrate for assay of erythrocyte sedimentation rate, $2 \mathrm{ml}$ were anticoagulated with EDTA for complete blood picture(using Coulter
T660 cell counter) and the remaining blood were left to clot and sera were separated for assay of:

-Routin laboratory investigations That previously mentioned:

-Estimation of Interleukin-8 : using IL-8 ELISA kit (Diaclone Researsh, France). It is solid phase sandwich ELISA. A monoclonal antibody specific for IL-8 had been coated the microplates. Standards ,samples ,controls and biotinylated polyclonal antibody specific for IL- 8 were incubated and after washing the enzyme streptavidinperoxidase was added after second incubation and washing a substrate (chromogen TMB) was added and after incubation color reaction was stopped and intensity of color was read at 450 $\mathrm{nm}$ and $620 \mathrm{~nm}$ as reference wavelength. The results were expressed as $\mathrm{pg} / \mathrm{ml}$.

-Estimation of sICAM-1 was done using human Parameter sICAM-1 immunoassay kit ( R\&D Systems, Germany).It is solid phase enzyme linked- immuno-sorbent assay (ELISA) employing the quant -itative sandwich enzyme immunoassay technique. Standards, samples, controls and conjugates (horseradish peroxidase conjugated to recombinant antibodies to human ICAM-1) were pipeted into wells of microplates coated with monoclonal antibodies against human sICAM-1 and any sICAM-1 presesnt was sandwiched between immobilized antibody and the enzyme-linked monoclonal antibodies specific for sICAM-1. Following washing, substrate (tetramethylbenzadine) was added and color developed in proportion to the amount of sICAM-1 bound. The color development was stopped and the intensity of the color was measured at wavelength $450 \mathrm{~nm}$ and $620 \mathrm{~nm}$ as reference wavelength. The results were expressed as $\mathrm{ng} / \mathrm{ml}$. 


\section{Statistical analysis:}

The data were analyzed using the Statistical Package for Social Science (SPSS 8) and expressed as mean \pm SD. Paired-sample $t$ test for comparison and Spearman correlation were used. $\mathrm{P}<$ 0.05 was considered significant.

\section{Results:}

According to endoscopic and histopathological findings, 16 out of the 40 patients had active UC (activity score 2-3 ), 12 had inactive UC( activity score $0-1$ ) and 12 had normal mucosa and served as a control (figure 1).

The results of ESR (mean \pm SD ) in active, inactive and control groups were $62.8 \pm 14 \mathrm{~mm}, 14 \pm 6 \mathrm{~mm}$ and $8.1 \pm 3 \mathrm{~mm}$ respectively. The mean $\pm \mathrm{SD}$ of $\mathrm{CRP}$ in active group was $57 \pm 44 \mathrm{mg} / \mathrm{L}$. Inactive and control groups were negative for CRP.

Serum IL-8 level showed significant increase in patients with active UC as compared to control and to non active group (tables $1 \& 2$, figure 2), while there was non significant differences between inactive patients and control group ( $p>0.05$, table 3$)$. Similarly, the mucosal IL-8 concentration showed significant rise in patients with active UC as compared to control and to non active group ( tables $1 \& 2$, figure 3 ).

On the other hand, there was non significant change in mucosal IL-8 in patients with non active UC as compared to the control $\operatorname{group}(\mathrm{p}>0.05$, table 3).

The results of sICAM-1 in sera showed significant increase in patients with active UC as compared to the control and to non active group $(\mathrm{p}<0.01$,tables $1 \& 2$, figure 4$)$. On the other hand there was non significant difference in serum sICAM-1 level between inactive UC and control group $(p>0.05$, table 3 ). As regarding the concentrations of sICAM- 1 in the supernatant of sonicated mucosa, they also showed significant increase in patients with active UC as compared to control groups and to non active group $(\mathrm{p}<0.01$, tables $1 \& 2$, figure 4 ), while there was non significant difference between non active and control $\operatorname{group}(\mathrm{p}>0.05$, table 3$)$.

The results of this study showed that both IL-8 and SICAM-1 in sera and mucosa of patients with active UC were positively correlated with ESR , CRP and disease activity (table 4 ). Also, IL-8 showed significant positive correlation with sICAM-1 in sera and tissue of patients with active UC (table 4).

Table (1):Results (mean \pm SD) of serum and tissue IL-8 (pg/ml) and sICAM-1 (ng/ml) in patients with active UC as compared to control group.

\begin{tabular}{|c|c|c|c|c|}
\hline & $\begin{array}{c}\text { Active } \\
(\mathrm{n}=16)\end{array}$ & $\begin{array}{c}\text { Control } \\
(\mathrm{n}=12)\end{array}$ & $\mathrm{t}$ & $\mathrm{p}$ \\
\hline S.IL-8 & $1100 \pm 583$ & $229 \pm 80$ & 4.643 & $<0.001$ \\
T.IL-8 & $77 \pm 9.9$ & $8.9 \pm 4.9$ & 20.96 & $<0.001$ \\
S.sICAM-1 & $603 \pm 121$ & $196 \pm 88$ & 15.354 & $<0.001$ \\
T.sICAM-1 & $58 \pm 19$ & $6.7 \pm 2.4$ & 8.488 & $<0.001$ \\
\hline
\end{tabular}

$\mathrm{P}<0.001=$ significant

$\mathrm{S}=$ Serum

$\mathrm{T}=$ Tissue 
Table(2): Results (mean \pm SD) of serum and tissue IL-8 (pg/ml)and sICAM-1 (ng/ml) in patients with active UC as compared to non active group.

\begin{tabular}{|c|c|c|c|c|}
\hline & $\begin{array}{c}\text { Active } \\
(\mathrm{n}=16)\end{array}$ & $\begin{array}{c}\text { Non active } \\
(\mathrm{n}=12)\end{array}$ & $\mathrm{t}$ & $\mathrm{p}$ \\
\hline S.IL-8 & $1100 \pm 583$ & $294 \pm 100$ & 4.675 & $<0.001$ \\
T.IL-8 & $77 \pm 9.9$ & $12.5 \pm 4.4$ & 26.985 & $<0.001$ \\
S.ICAM-1 & $603 \pm 121$ & $260 \pm 88$ & 6.924 & $<0.001$ \\
T.ICAM-1 & $58 \pm 19$ & $8.9 \pm 3.8$ & 7.616 & $<0.001$ \\
\hline
\end{tabular}

$\mathrm{P}<0.001=$ significant

$\mathrm{S}=$ Serum

$\mathrm{T}=$ Tissue

Table (3): Results (mean \pm SD) of serum and tissue IL-8 (pg/ml) and sICAM-1 (ng/ml) in patients with non active UC as compared to control group.

\begin{tabular}{|c|c|c|c|c|}
\hline & $\begin{array}{c}\text { Non active } \\
(\mathrm{n}=12)\end{array}$ & $\begin{array}{c}\text { Control } \\
(\mathrm{n}=12)\end{array}$ & $\mathrm{t}$ & $\mathrm{P}$ \\
\hline S.IL-8 & $294 \pm 100$ & $229 \pm 80$ & 1.8 & $\mathrm{p}>0.05$ \\
T.IL-8 & $12.5 \pm 4.4$ & $8.9 \pm 4.9$ & 1.683 & $\mathrm{p}>0.05$ \\
S.sICAM-1 & $260 \pm 88$ & $196 \pm 88$ & 1.901 & $\mathrm{p}>0.05$ \\
T.sICAM-1 & $8.9 \pm 3.8$ & $6.7 \pm 2.4$ & 1.971 & $\mathrm{p}>0.05$ \\
\hline
\end{tabular}

$\mathrm{p}>0.05=$ non significant

$\mathrm{S}=$ Serum

$\mathrm{T}=$ Tissue

Table (4): Correlations between serum and tissue IL-8 and ESR,CRP and activity score and between serum and tissue sICAM-1 and ESR,CRP and activity score and between Il-8 and sICAM-1 in active UC patient group.

\begin{tabular}{|l|c|c|c|c|}
\hline \multirow{2}{*}{} & \multicolumn{2}{|c|}{ Serum } & \multicolumn{2}{c|}{ Tissue } \\
\cline { 2 - 5 } & $\mathrm{r}$ & $\mathrm{p}$ & $\mathrm{r}$ & $\mathrm{p}$ \\
\hline IL-8/ESR & 0.702 & $<0.01$ & 0.760 & $<0.01$ \\
IL-8/CRP & 0.555 & $<0.05$ & 0.669 & $<0.01$ \\
IL-8/Activity score & 0.585 & $<0.05$ & 0.546 & $<0.05$ \\
sICAM-1/ESR & 0.853 & $<0.01$ & 0.780 & $<0.01$ \\
sICAM-1/CRP & 0.885 & $<0.01$ & 0.718 & $<0.01$ \\
sICAM-1/Activity score & 0.657 & $<0.01$ & 0.759 & $<0.01$ \\
SICAM-1/IL-8 & 0.642 & $<0.01$ & 0.867 & $<0.01$ \\
\hline
\end{tabular}

$\mathrm{P}<0.05=$ significant 


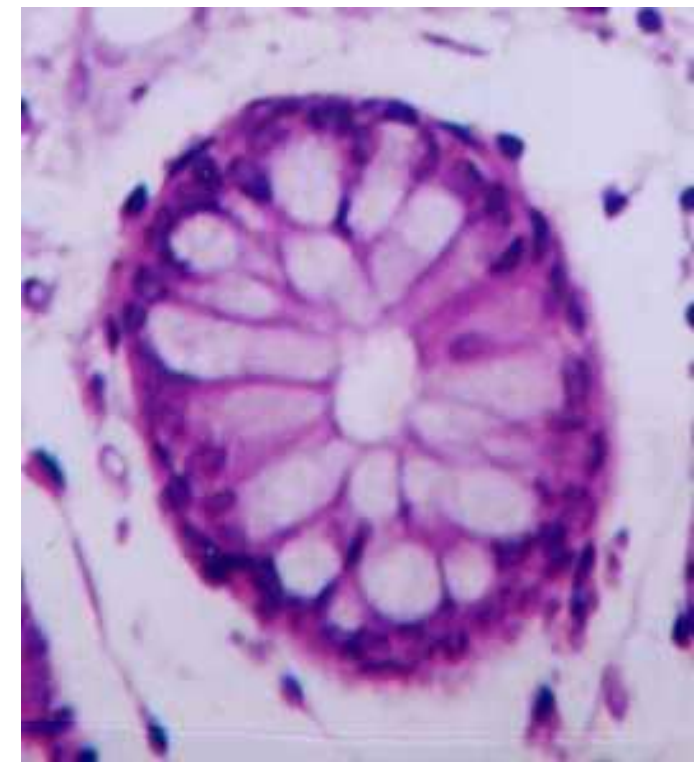

A

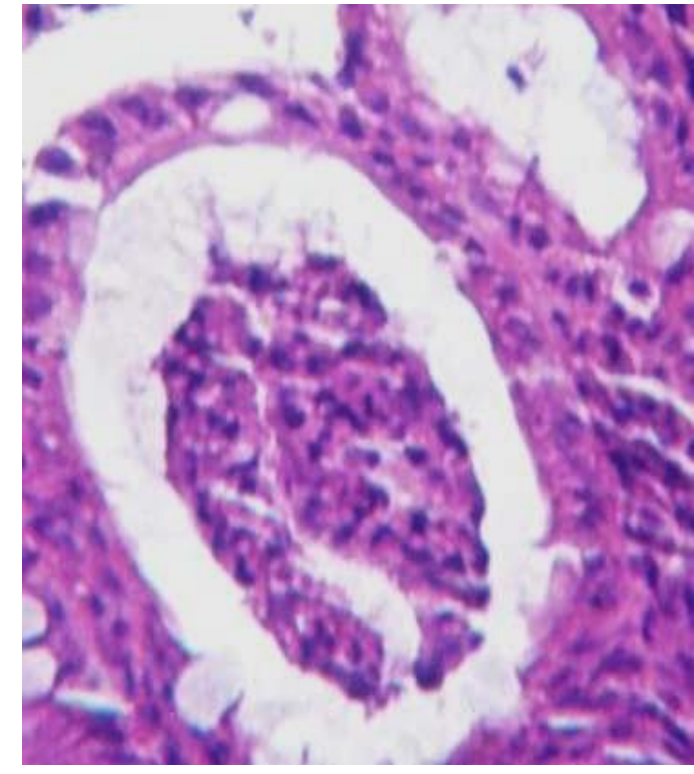

B

Figure (1): A - Normal colonic mucosa - B - colonic mucosa with crypt abscess and dense neutrophil infiltration (score 2)

Figure(2):Mean serum IL -8 in active and inactive UC and control group

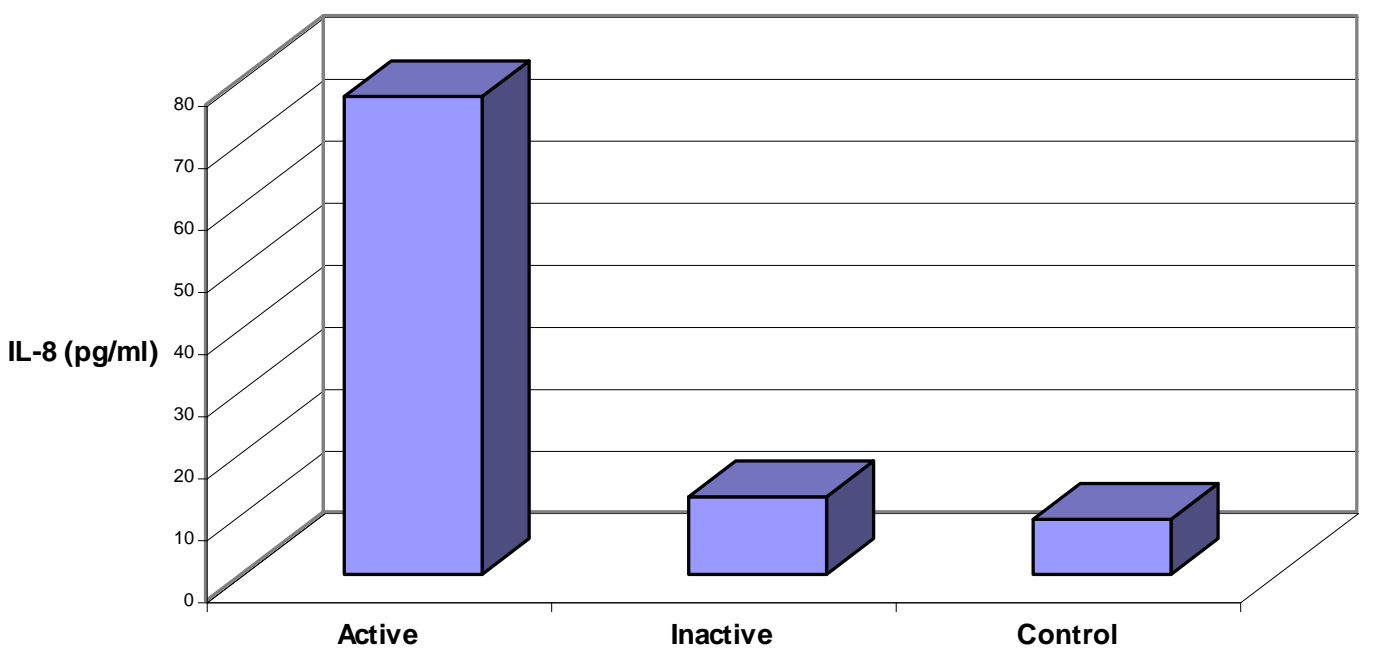




\section{Mona M. Morsy et al}

Figure(3):Mean tissue IL -8 in active and inactive UC and contorl group

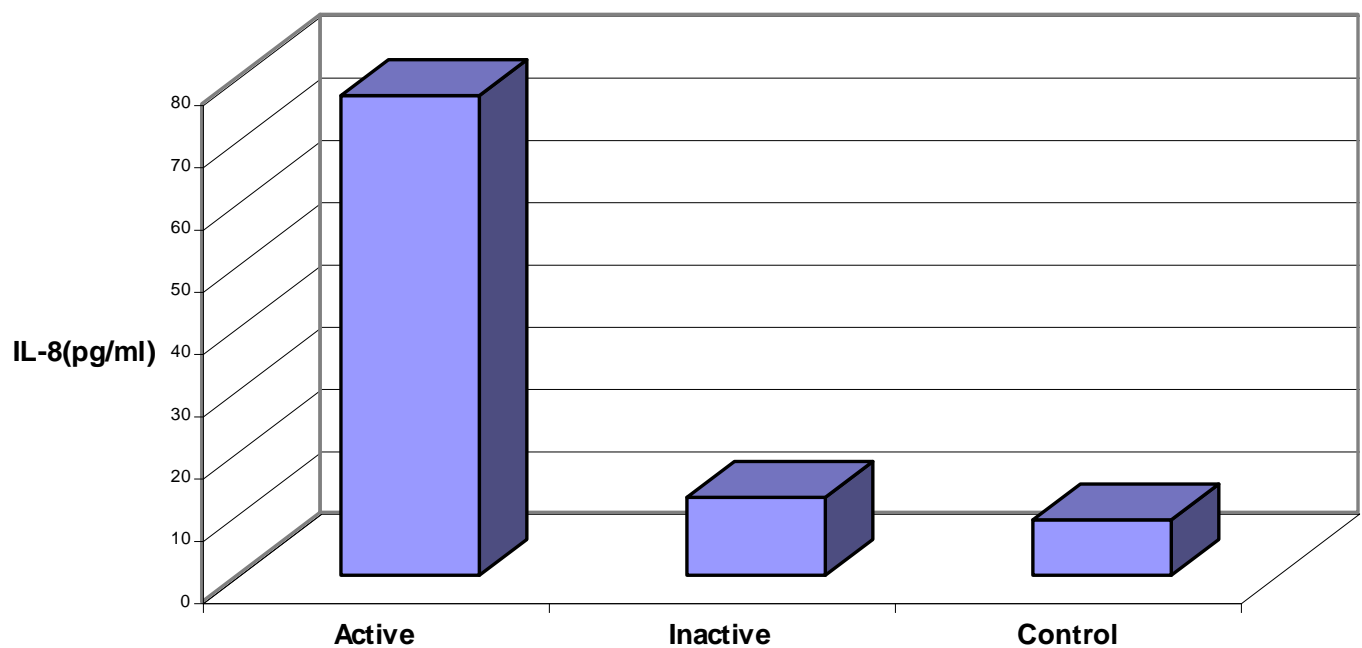

Figure(4): Mean Serum sICAM -1 level in active and inactive UC and control group

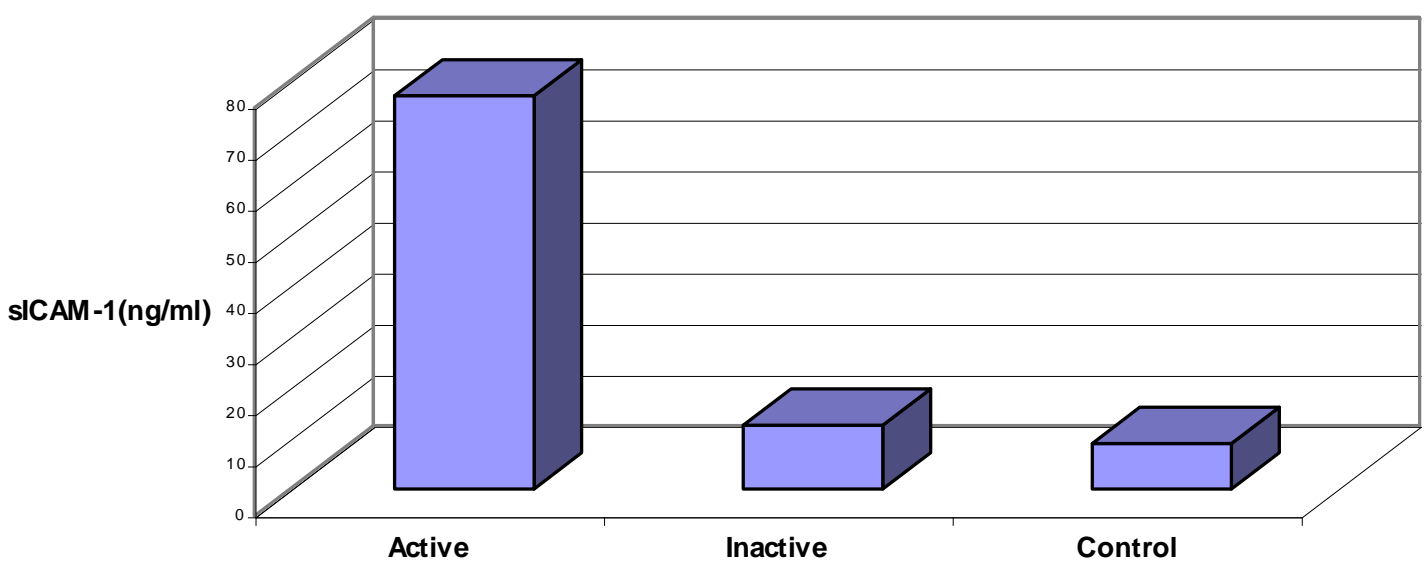

Figure(5):Mean Tissue sICAM -1 level in active and inactive UC and control groups

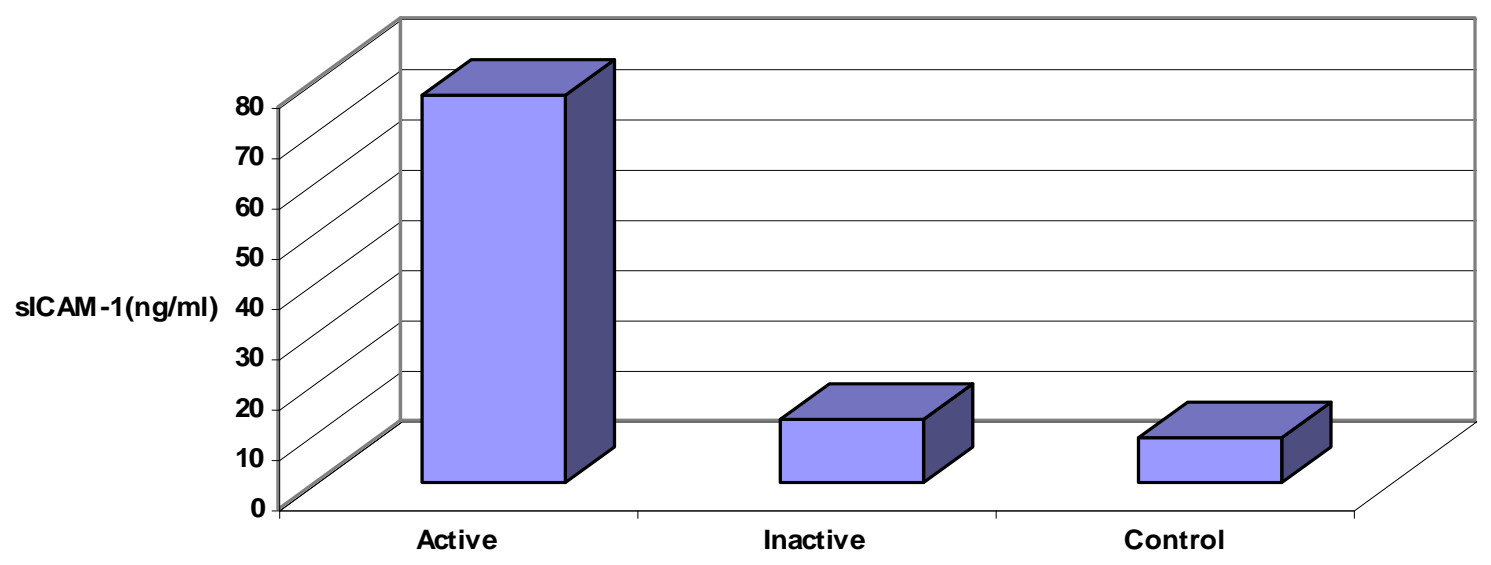




\section{Discussion}

Ulcerative colitis has been viewed as chronic disease of the colon, however the disease has an acute component marked by increased migration of neutrophils from circulation into the inflamed mucosa (Carlson et al.,2001). Although the aetiology of ulcerative colitis (UC) remains unknown, there is general agreement that the mucosal inflammatory response is probably induced by disorders of immune mechanisms, however, the develop ment of the disease may be triggered by bacterial, viral, environmental, or other factors and that the inflammatory process is ultimately caused by excessive mucosal generation of cytok ines and inflammatory mediators (Lakatos, 2000).

Although proinflammatory cytok ines are believed to be involved in the pathogenesis of UC, but it has not yet been clarified which is the most important one in the inflammatory response in active UC (MaCormack et al.,2001). Interleukin -8 is an important chemokine that recruits and activates neutrophils which are abundant in the intestinal lesions of UC ( Imada et al., 2001). In the present study, serum and mucosal IL-8 levels showed significant increase in patients with active $\mathrm{UC}$ as compared to non- active UC and control groups $(\mathrm{p}<0.001)$. IL-8 was positively correlated with ESR $(p<0.01)$, CRP $(\mathrm{p}<0.05)$. and with histopathological grading (activity) $(\mathrm{p}<0.05)$ in patients with active UC. In agreement with our results Nielsen et al., (2000), found that IL-8 was significantly increased in active UC specimens and was positively correlated with the disease activity, ESR and CRP. It has been reported that increased local production of Il-8 in UC in active stage is probably caused by both an increased number and enhanced activity of macrophages
(Suziki et al.,1999). Also, it was suggested that the increased IL-8 production in the inflamed mucosa may play a role in stimulating the influx of neutrophils into areas of active inflammation and that neutrophils activated by IL- 8 may also induce mucosal injury by the release of lysozomal enzymes, leukotriene $\mathrm{B}_{4}$ and toxic free radicals ( Ishguro ,1999).

Intercellular adhesion molecule 1 (ICAM-1) is of paramount importance for the initiation and propagation of various inflammatory conditions (Braun et al., 2001).It is also suggested to be involved in the further migration of leucocytes toward the epithelial lining in ulcerative colitis(Vainer et al., 2001). In the present study serum and mucosal sICAM-1 concentrations showed significant increase in patients with active UC as compared to control and non active groups $(\mathrm{p}<0.001)$, but no difference was found between non active and control group ( $\mathrm{p}>0.05)$. These results are in agreement with those obtained by Vainer and Nielsen,(2000) and Goggins et al., (2001). The present study also revealed a significant positive correlation between sICAM, (in serum and tissue) and ESR $(\mathrm{p}<0.01)$, as well as CRP $(\mathrm{p}<0.01)$ acute phase reactants and activity score $(p<0.01)$. Parallel to our results those obtained by Nielsen et al., (1996).

The results of the presesnt study also showed significant positive correlation between IL-8 and SICAM-1 (in sera and tissue) in patients with active UC. These results are parallel to those obtained by Nielsen et al.,(1998) who found significant positive correlation between SICAM-1 and IL-8 in mucosa of patients with UC. In conclusion, both sICAM-1 and IL-8 were significantly elevated in patients 
with active UC as compared to control group and inactive cases, denoting that they might play a role in the perpetuation of tissue destructive inflammatory process. The increased mucosal sICAM-1 may reflect increased adhesiveness and more involvement of ICAM-1 in leucocyte migration in mucosa of active UC. Also,the serum concentrations of Il- 8 and sICAM-1 may be used as simple non-invasive tests for monitoring the disease activity in patients with ulcerative colitis.

\section{References:}

1. Braun C., Zahn R., Martin K. (2001): and Albert E: Polymorphisms of the ICAM-1 gene are associated with inflammatory bowel disease, regards of the P-ANCA status. Clin.Immunol; 101:357-360.

2. Carlson M., Raab Y., Seveus L. and Xu S. (2001):Human neutrophil lipoc alin is a unique marker of neutrophil inflammation in ulcerative colitis and proctitis. Gut,50:501-506.

3. Cellier C., Paty N.,GervoniJ.P., Leborgen $M$. and Chaussade $S$. (1997): In-situ endothelial cell adhesion molecule expression in ulcerative colitis. E- selectin in-situ expression correlates with clinical, endoscopic and histological activity and outcome. Eur.J. Gastroenterol, Hepatol.;9:1197-1203.

4. Goggins M.G., Goh J., O'Connell M.A. and Weir D.G. (2001): Soluble adhesion molecules in inflammatory bowel disease. J. Med.Sci.; 170:107111.

5. Imada A., Ina K., Shimada M., Yokoyama T., Nisio Y. and Ando T (2001): Coordinate upregulation of interleukin- 8 and growth- related gene product-alpha is present in the colonic mucosa of inflammatory bowel. Scand. J. Gastroenterol.; 36:854-864.

6. Ishiguro Y.(1999): Mucosal proinfla mmmatory cytokine production corr elates with endoscopic activity of ulcerative colitis.J. Gastroenterol.; 37:66-74.

7. Lakatos L. (2000): Immunology of inflammatory bowel diseases. Acta Physiol. Hung.87:355-372.

8. Langholz E., Munkholm P, Nielsen O.H., Kreiner S. and Binder V.(1991): Incidence and prevalence of ulcerative colitis in Copenhagen county from 1962 to $1987 . \quad$ Scand.J Gastroenterol.; 26: 1247-1256.

9. MacDermott R.P., Sanderson I.R., and Reinecker H.C. (1998): The central role of chemokines (chemotactic cytokines) in the immunopathogenesis of ulcerative colitis and Chron's disease. Inflam.Bowel Dis.; 4:54-67.

10. McCormack G., Moriarty D., O'Donoghue D., Sheahan K. and Baird A. (2001) : Tissue cytokine and chemokine expression in inflammatory bowel disease. Inflamm.Res.; 50:491495.

11. Nakata B., Hori T.,Sunami T. Ogawa Y., Yashiro M. and Maeda K.(2000): Clinical significance of serum soluble intercellular adhesion molecule-1 in gastric cancer. Clin.Cancer Res.; 6:1175-1179.

12. Natarajan R., Ghosh S., Fisher B.J., Deigelmann R.F., and Walash S. (2001): Redox imbalance in Chron's disease intestinal smooth muscle cells cause NF-kappa B-mediated spontan eous interleukin-8 secretion. J. Interferon Cytokine Res.; 21:349-359.

13. Nielsen O.H., Langholz E., Hendel J. and Brynskov J. (1996): Circulating soluble intercellular adhesion molecule1 (sICAM-1) in active inflammatory bowel disease.

14. Neilsen O.H., Brynskov $\mathbf{J}$ and Vainer B. (1998): Increased mucosal concentrations of soluble intercellular adhesion molecule-1 (sICAM-1), sEselectin and interleukin- 8 in active ulcerative colitis. Digestive diseases and sciences.; 41:1780-1785.

15. Nielsen O.H., Vainer B., Madsen S.M., Seidelin J. and Heegaard N.(2000): Established and emerging biological activity markers of 
inflammatory bowel disease .Am.j.

Gastroenterol.; 95:359-367.

16. Pedersen G., Brynskov J. and Nielsen O.H.( 1995) : Adhesion molecules in inflammatory and neoplastic intestinal diseases. Dig. Dis.; 13 :322-336.

17. Pepys M.B. and Berger A. (2001): The renaissance of $\mathrm{C}$ reactive protein. BMJ ; 322:4-5.

18. Taha A.S., Grant V., and Kelly R.W.(2001): Urine analysis for interleukin-8 in the non-invasive diagnosis of acute and chronic inflammatory diseases. Postgrad. Med. J.;79:159-168.

19. Truclove S.C. and Richard W.C.D. (1956): Biopsy studies in ulcerative colitis. Br.Med.J.; 1:1315-1318.

20. Uguccioni M., Gionchetti P., Robbinani D.F., Rizzello F. and Peruzzo S.(1999): Increased expression of IP-10, Il-8, MCP-1 and MCP-3 in ulcerative colitis. Am. J. Pathol.; 155:331-336.
21. Vainer B. and Nielsen O.H. (2000): Changed colonic profile of P-selectin, platelet-endothelial cell adhesion mole cule-1 (PECAM-1), intercellular dhesion molecule-1 (ICAM-1),ICAM2 , and ICAM-3 in inflammatorybowel disease. Clin.Exp.Immunol.;121:242247.

22. Vainer B. , Nielsen O.H. and Horn T. (2000): Comparative studies of the colonic in situ expression of interce llular adhesion molecules (ICAM-1,-2, and-3),beta2 integrins (LFA-1, Mac-1 and p150,95) and PECAM-1 in ulcerative colitis and Chron's disease. Am.j.Surg.Pathol.; 24:1115-1124.

23. Vainer B., Sorensen S., Nielsen O.H and Horn T. (2001): Subcellular localization of intercellular adhesion molecule-1 in colonic mucosa in ulcerative colitis. Ultrastruc. Pathol. ;26:1130121 
الإنترلوكين - 8 و الجزيء الخلوي اللاصق -1 الأبائ فى مرضى الالتهاب القولوني المتثرح الاصث

\section{منى محمد مرسى ، ماجدة إبراهيم محمد المهلى* ، وفاء حلمي عباس

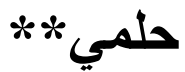 \\ أقسام الباطنة العامة ، الباثولوجيا الإكلينيكية** و الباثولوجيا العامةث* * كلية الطب بنات. - جامعة الأزهر}

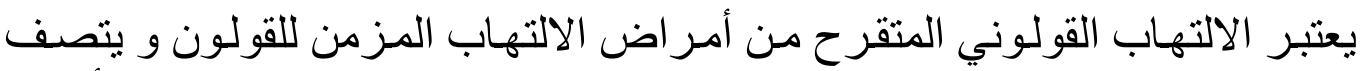

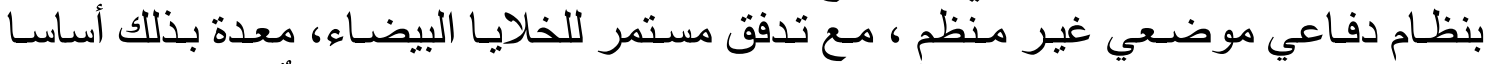

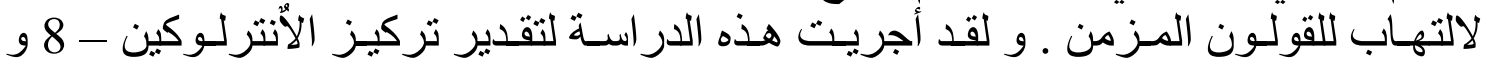

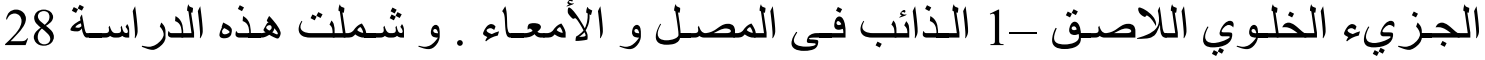

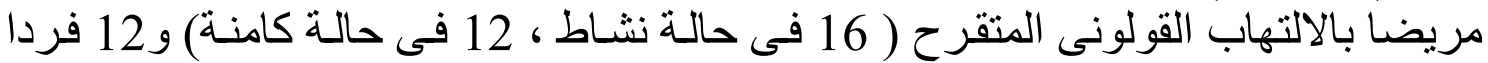
كمجمو عة ضابطة ـ ولقد تم عمل الفحوصات التالية للمرضى و المجمو عة الضابطة : منظار

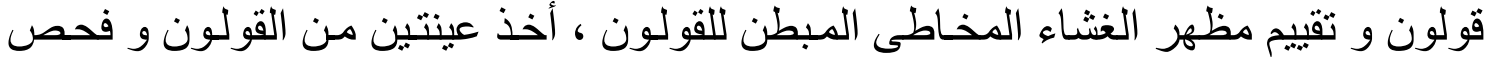

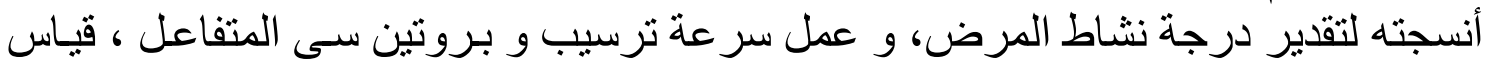

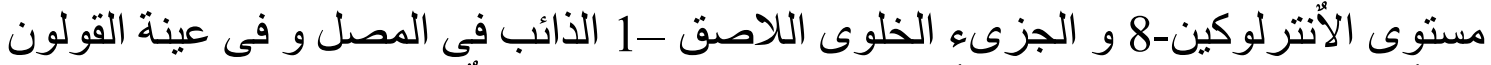

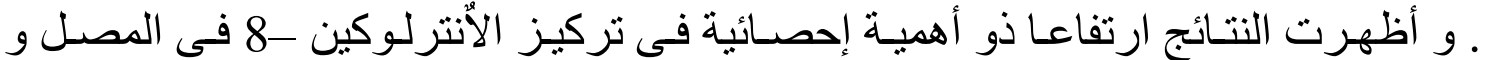

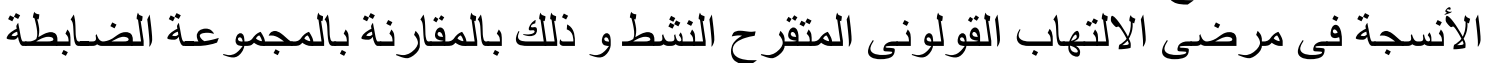

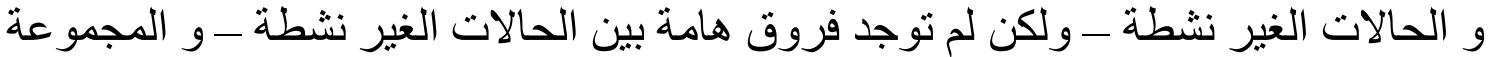

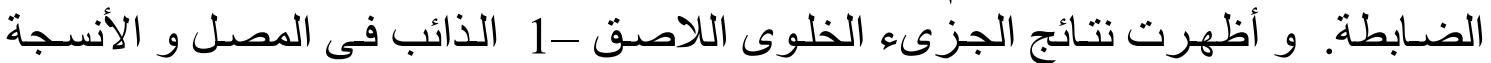

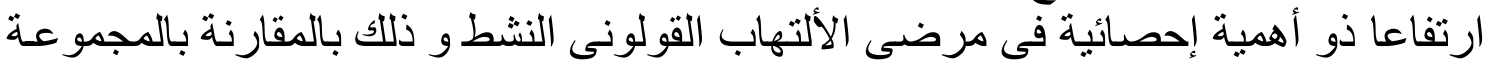

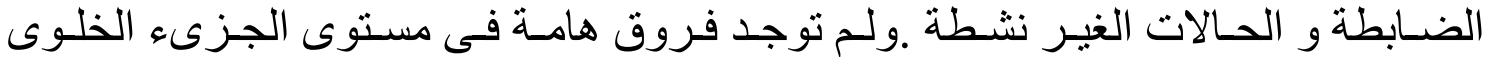

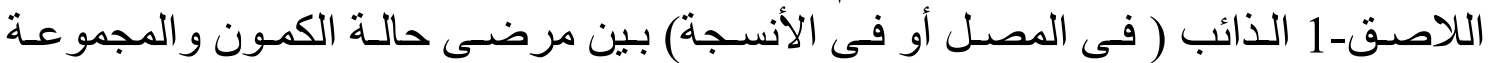

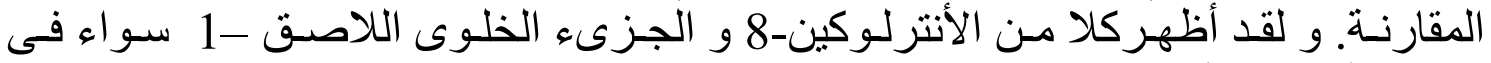

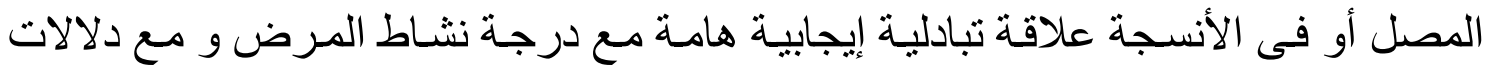

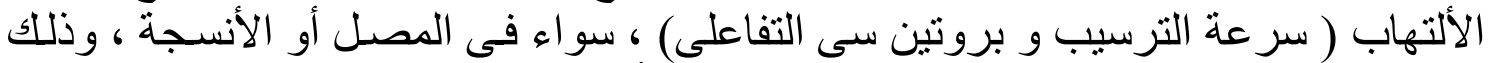

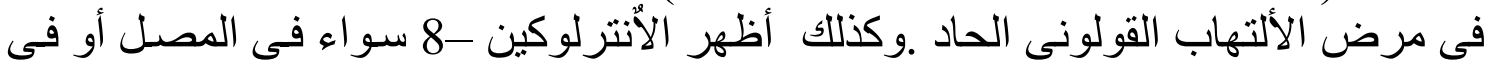

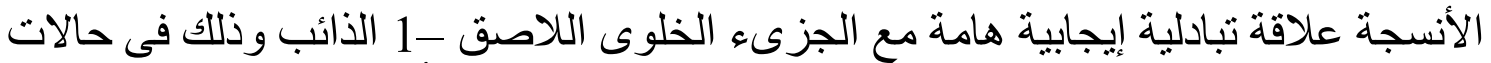

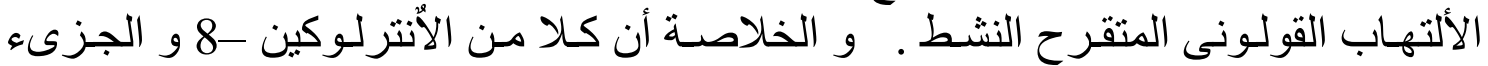

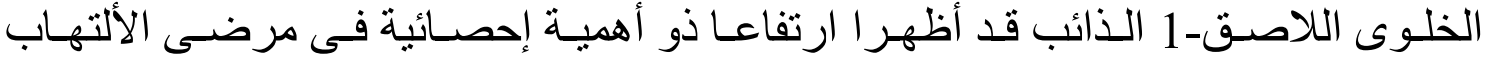
القولونى المتقرح النشط وذلك بالمقارنة مع المجمو عة الضابطة و الحالات الغير نشطة.

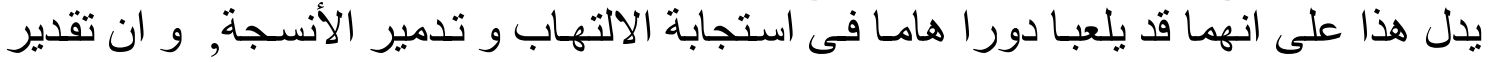

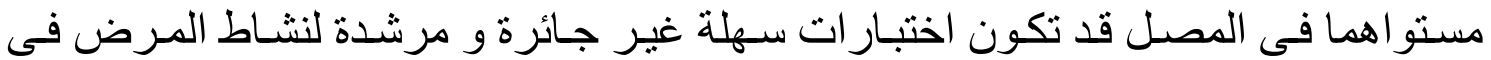
مرضى الألتهاب القولونى المتقرح 